American Journal of Animal and Veterinary Sciences 4 (1): 1-5, 2009

ISSN 1557-4555

(C) 2009 Science Publications

\title{
Genetic Diversity of Red Chittagong Cattle Using Randomly Amplified Polymorphic DNA Markers
}

\author{
${ }^{1}$ Mohammad Masud Rana Mufti, ${ }^{1}$ Mst. Parvin Mostari, ${ }^{1}$ Gautam Kumar Deb, \\ ${ }^{2}$ K. Nahar and ${ }^{1}$ Khan Shahidul Huque \\ ${ }^{1}$ Animal Production Research Division, \\ Bangladesh Livestock Research Institute, Savar, Dhaka-1341, Bangladesh \\ ${ }^{2}$ Department of Zoology, University of Dhaka, Bangladesh
}

\begin{abstract}
Problem statement: Red Chittagong Cattle (RCC) is a potential genetic resource in Bangladesh having dairy potentialities, high resistance to disease and survive harse environmental condition while require low input supply. This resource is now disappearing due to indiscriminate crossing with other local and exotic cattle. To conserve this resource, find out the genetic diversity of RCC is prime concern. Approach: To determine the genetic variation of Red Chittagong Cattle and to find out the genetic present status for their future improvement and conservation program. The experiment was conducted in the Molecular Genetics Laboratory under Animal Production Research Division, Bangladesh Livestock Research Institute (BLRI), Saver, Dhaka, Bangladesh. DNA was extracted from 100 RCC blood samples and the extracted DNA was observed by gel electrophoresis. Randomly 16 primers were tested among them three primers were matched and found polymorphic. Random Amplification of Polymorphic DNA-Polymerase Chain Reaction (RAPD-PCR) analysis was carried out using DNA samples of RCC. Only unambiguous, reproducible and scorable polymorphic fragments were taken into consideration for analysis. Data were analyzed by using a computer program POPGENE (Version 1.31). Results: The highest and the lowest level of gene frequency value $(0.9590$ and 0.0440) were observed in allele 0 and 1 with BMC1222-2 locus and only one monomorphic locus (OPB07-1) was found. The Nei's gene diversity and Shannon's information indicated that the highest and the lowest diversity were found in Anwara (0.2925) and Chandonish (0.2147) respectively. The pair-wise mean genetic distance value ranged (below diagonal) from 0.0092-0.0279. The minimum distance was found between Satkania and Chandonish. On the other hand maximum distance was found between RCC BLRI and Potia. The dendrogram segregated the five population of RCC into two clusters: RCC BLRI and Anwara is one cluster whereas Satkania, Chandonish and Potia made another cluster. Conclusion: The genetic diversity of RCC is relatively higher for a prescribed breed and therefore, have an opportunities to improve them using selective breeding like ONBS.
\end{abstract}

Key words: Red chittagong cattle, RAPD, PCR, genetic variation, genetic distance

\section{INTRODUCTION}

Red Chittagong Cattle (RCC) is a potential and promising animal genetic resource in Bangladesh. It is a dwarf type, red color, having dairy potentialities, high resistance to disease and survive harse environmental condition while require low input supply. The productive and reproductive performance of RCC comprises; daily milk yield, lactation length, age at puberty, service per conception and post partum heat period are $2.46 \pm 0.40 \mathrm{~kg}^{[1]}, 283 \pm 58.7^{[1]}, 33.41 \pm 4.23$ months ${ }^{[2]}, \quad 1.47 \pm 0.61^{[2]}$ and $54.28 \pm 9.64$ days $^{[2]}$ respectively. The milk fat $\%$ is 6 , which is higher than other dairy breed.

Like other developing countries, breed substitution and crossbreeding program has been practiced indiscriminately in Bangladesh for many years with exotic breed and as a result valuable genetic resources is being lost or diluted day by day. Assessment of genetic variation is a crucial element in determining breeding strategies and for effective and meaningful conservation program ${ }^{[3]}$.

Genetic diversity or similarity may be measured through genetic markers. These have been used to

Corresponding Author: Mohammad Masud Rana Mufti, Animal Production Research Division,

Bangladesh Livestock Research Institute, Savar, Dhaka-1341, Bangladesh

Tel: +8801912690029/+8801717345038 Fax: +88 027791675 
determine evolutionary relationship within and between species, genera or higher taxonomic categories ${ }^{[4]}$ However, breeders tend to concentrate on specific genotypes for determination of genetic diversity, which combine traits of interest and may be used as progenitors in several breeding programs in order to introduce agro-ecological important traits. In an attempt to solve the problem of maintaining pure breeds using the observed morphological characteristics that require a lot of time and effort, the use of molecular markers in maintaining cattle breeds is more suitable and less time consuming. Moreover, molecular markers are important tools in tagging desirable loci underlying the traits which have breeding importance.

Molecular markers are the molecules that could be used to trace a desired gene(s) in examined genotypes. In fact, a piece of DNA or a protein can be used as a marker. Earlier approaches that made selection of specific traits easier were based on the evaluation of morphological traits ${ }^{[5]}$ RAPDs $^{[6]}$ storage proteins like hordeins ${ }^{[7]}$. However, DNA markers seem to be the best candidates for efficient evaluation and selection of animal population. Unlike protein markers, DNA markers segregate as single genes and they are not affected by the environment as morphological markers. Presently, the PCR-based RAPD fingerprinting assays are being used for characterization of zebu cattle breeds ${ }^{[8]}$, for detection of genetic variations in cattle and sheep ${ }^{[9]}$.

Estimation of genetic variation increasingly is being based upon information at the DNA level by various molecular markers such as, RAPD, AFLP, RFLP, SSR or Microsatellite. Among them, RAPD markers, generated by the Polymerase Chain Reaction (PCR) is widely used since 1990's to assess infraspecific genetic variation at nuclear level ${ }^{[10,11]}$. This procedure detects nucleotide sequence polymorphisms in a DNA amplification-based assay using only a single primer of arbitrary nucleotide sequence. The polymorphism between individuals result from sequence differences in one or both of the primer binding sites and are visible as the presence or absence of a particular RAPD band. The aim of this work is to determine the genetic variation and relatedness of Red Chittagong Cattle and to find out the present status for their future improvement and conservation programme.

\section{MATERIALS AND METHODS}

This experiment was conducted in the Molecular Genetics Laboratory under Animal Production Research Division, Bangladesh Livestock Research
Institute (BLRI), Saver, Dhaka, Bangladesh. In this chapter details of different materials used and methodologies followed for the study have been described.

Collection of blood: One hundred blood samples were collected from RCC; 40 from Bangladesh Livestock Research Institute (BLRI) RCC Farm and 60 from four areas (Anwara, Potia, Chandonish, Satkania) of Chittagong district. Blood were taken from the jugular vein using specialized vacuum blood collection vial in which EDTA was used as an anticoagulant. The samples were kept at $-20^{\circ} \mathrm{C}$ until the study start.

Extraction of genomic DNA: Genomic DNA was extracted from blood following the method described by $^{[12]}$ with some modifications. $500 \mu$ l of blood was taken in a microcentrifuge tube and breaks the cell membrane with 1X Standard Saline Citrate (SSC) buffer. Then protein were precipitated by sodium acetate and digested with proteinase $\mathrm{K}$ at $55^{\circ} \mathrm{C}$ for $1 \mathrm{~h}$. After that, aquous layer was removed by Phenol: Chloroform: Isoamyle alcohol (25: 24:1) and pricipitated with $100 \%$ ethanol. DNA was reprecipitated and washes with $\mathrm{Na}$ acetate and $70 \%$ ethanol. Finally DNA samples were dried and dissolved in TE buffer and stored at $-20^{\circ} \mathrm{C}$ until use.

Gel documentation: Extracted DNA was confirmed by electrophoresis separation on $1 \%$ agarose gel staining with ethidium bromide.

DNA quantification: Ultraviolet (UV) spectrophotometer was used for the quantification of DNA concentration. For the quantification of DNA, $260 \mathrm{~nm}$ absorbance is recommended ${ }^{[13]}$. Doublestranded DNA was calculated by using the following formula:

DNA concentration $\left(n g \mathrm{~L}^{-1}\right)=$

$\frac{\text { Absorbance } \times \text { volume of distilled water }(\mu \mathrm{L})}{\text { Amount of DNA sample }(\mu \mathrm{L})} \times$ Conversion factor $(0.05) \times 1000$

Primer selection: Randomly 16 primers were tested among them three primers were matched and found polymorphic. These primer sequences are shown in Table 1.

Table 1: Primer matched

\begin{tabular}{llc}
\hline Primer code & Primer sequence 5 $^{\prime}$ - $^{`}$ & GC content $(\%)$ \\
\hline OPA 02 & TGCCGAGTCG & 70 \\
OPB 07 & GGTGACGCAG & 70 \\
BMC1222 & CCTGAGTGTTCCTCCTGAGT & 55 \\
\hline
\end{tabular}


Table 2: Estimation of gene frequency

\begin{tabular}{lllllllllllllll}
\hline Allele/ & LPA02-1 & OPA02-2 & OPA02-3 & OPA02-4 & OPB07-1 & OPB07-2 & OPB07-3 & OPB07-4 & OPB07-5 & BMC122-1 & BMC122-2 & BMC122-3 & BMC122-4 \\
\hline Locus & OPAle 0 & 0.572 & 0.563 & 0.749 & 0.569 & - & 0.343 & 0.649 & 0.624 & 0.436 & 0.704 & 0.956 & 0.853 & 0.093 \\
Allele 1 & 0.428 & 0.437 & 0.251 & 0.431 & 1.000 & 0.657 & 0.351 & 0.376 & 0.564 & 0.296 & 0.044 & 0.147 & 0.907 \\
\hline
\end{tabular}

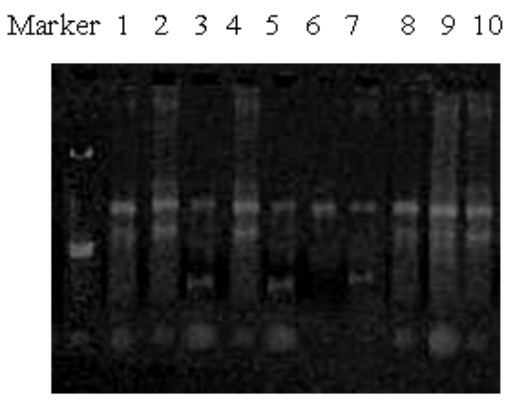

Fig. 1: RAPD Profiles of RCC using primer OPA-02

PCR amplification: PCR reactions were performed on each DNA sample in a $25 \mu \mathrm{L}$ reaction mix containing $4.0 \mu \mathrm{L}$ dNTPs of $2.5 \mathrm{mM}, 2.5 \mu \mathrm{L}$ of $10 \mathrm{X}$ Ampli Taq Polymerase buffer, $1.25 \mu \mathrm{L}$ of $50 \mathrm{mM} \mathrm{Mgcl}, 1 \mu \mathrm{L}$ of 100 p.mol $\mu \mathrm{L}^{-1}$ primer, $0.20 \mu \mathrm{L}$ of Taq polymerase $\left(5 \mathrm{U} \mu \mathrm{L}^{-1}\right), 4.0 \mu \mathrm{L}$ of DNA template and suitable amount of distilled water. PCR cycling conditions were: $3 \mathrm{~min}$ at $94^{\circ} \mathrm{C}$, followed by 30 cycles of $1 \mathrm{~min}$ at $94^{\circ} \mathrm{C}$, $1 \mathrm{~min}$ at annealing temperature $\left(32-38^{\circ} \mathrm{C}\right)$ of each primer, 2 min elongation at $72^{\circ} \mathrm{C}$ and final extension of $10 \mathrm{~min}$ at $72^{\circ} \mathrm{C}$.

Agarose gel electrophoresis: The amplified product from each sample was separated electrophoretically on $2 \%$ agrose gel containing ethidium bromide in $1 \mathrm{X}$ TAE buffer. DNA bands were observed under UV light on a UV transilluminator and photographed by a polarized camera. A molacular weight marker DNA (100 bp DNA Ladder) was elctrophoresed alongside the RAPD reactions.

Analysis of molecular data: Different measures of within breed genetic variations, namely number of alleles, allele frequencies ${ }^{[14]}$, gene diversity, Shanon's information index, genetic distance were estimated using the POPGENE software package ${ }^{[15]}$ with 1000 simulated samples to evaluate variability at DNA level.

\section{RESULTS}

Estimation of genetic similarity within and between breeds and genetic distance among different breeds of livestock is an important application of the
DNA based genetic markers. The above information is of immense importance in breed characterization and conservation studies as well as in selection programs as they are essential for efficient sampling and utilization of germ plasm resources and for making decisions regarding choice of parents ${ }^{[16]}$. In present investigation, genetic diversity was determined by the estimation of gene frequency, genetic variation, pair wise genetic distance and dendrogram illustration.

Gene frequency: Gene frequency measures the frequency in the population of a particular gene relative to other genes at its locus. In population genetics, gene or allele frequencies show the genetic diversity of a species population or equivalently the richness of its gene pool. The gene frequencies of RCC in different locations are shown in Table 2.

Genetic variation: Genetic variation is important because it provides the "raw material" for natural selection. Genetic variation is caused by variation in the order of bases in the nucleotides in genes. Genetic variation among individuals within a population can be identified at a variety of levels. It is possible to identify genetic variation from observations of phenotypic variation in either quantitative traits or discrete traits ${ }^{[17]}$. The genetic variation in RCC is shown as Nei's gene diversity, Shannon's information and proportion of polymorphic bands in Table 3 . Table 3 shows that the Nei's gene diversity was more or less similar for all populations and it ranges from 0.2147-0.2925. The proportion of polymorphic band was higher in Potia population $(76.92 \%)$ than others.

Pair wise genetic distance and dendrogram: Pair wise genetic distance and dendrogram indicates the genetic relationship among different groups. Nei's pairwise genetic distance, calculated between all pairs of 5 populations, is shown in Table 4 . The pair-wise mean genetic distance value ranged (below diagonal) from 0.0092- 0.0279 . The average pair wise genetic distance, 0.0155 was found among 5 populations.

Dendrogram stability is an important aspect to be considered in genetic variability studies ${ }^{[18]}$. A dendrogram based on genetic distance using the Unweighted Pair-Group Method of Analysis (UPGMA) is shown in Fig. 2. 
Table 3: Estimates of genetic variation

\begin{tabular}{llll}
\hline Population & $\begin{array}{l}\text { Nei's gene } \\
\text { diversity }\end{array}$ & $\begin{array}{l}\text { Shannon's } \\
\text { Information }\end{array}$ & $\begin{array}{l}\text { Proportion of } \\
\text { polymorphic bands (\%) }\end{array}$ \\
\hline RCC BLRI & 0.2259 & 0.3278 & 53.85 \\
Satkania & 0.2750 & 0.4010 & 69.23 \\
Potia & 0.2706 & 0.4046 & 76.92 \\
Chandonish & 0.2147 & 0.3160 & 53.85 \\
Anwara & 0.2925 & 0.4228 & 69.23 \\
\hline
\end{tabular}

Table 4: Pari-wise genetic distance among RCC population in different locations

\begin{tabular}{llllll}
\hline & RCC & & & & \\
& BLRI & Satkania & Potia & Chandonish & Anwara \\
\hline RCC BLRI & $* * * *$ & 0.9603 & 0.9568 & 0.9683 & 0.9895 \\
Satkania & 0.0229 & $* * * *$ & 0.9805 & 0.9872 & 0.9814 \\
Potia & 0.0279 & 0.0120 & $* * * *$ & 0.9820 & 0.9725 \\
Chandonish & 0.0235 & 0.0092 & 0.0102 & $* * * *$ & 0.9827 \\
Anwara & 0.0107 & 0.0112 & 0.0203 & 0.0173 & $* * * *$ \\
\hline
\end{tabular}

Nei's genetic identity (above diagonal) and genetic distance (below diagonal)

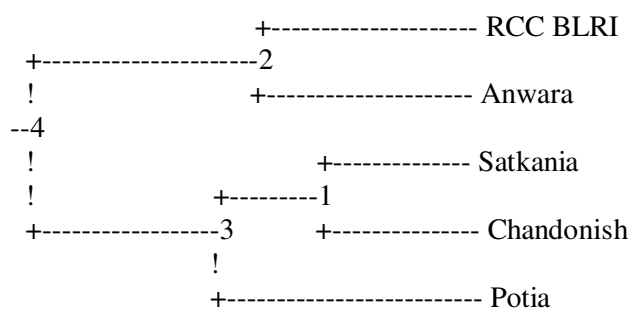

Fig. 2: UPGMA dendrogram based on $\mathrm{Nei}^{[18]}$ genetic distance summarizing the data on genetic differentiation in five populations of RCC using RAPD

\section{Discussion}

Among the 16 primer initially tested, three primers OPA-02, OPB-07 and BMC122 yielded polymorphic bands. They generated 13 distinct bands or RAPD markers, of which $12(93.31 \%)$ were considered as polymorphic. The DNA polymorphisms are detected by band presence versus band absence. Primer OPB-07 gave DNA profiles with more bands than OPA-02 and BMC1222. Figure 1 shown the RAPD profile of Red Chittagong cattle using primer OPA-02.

Although only three primers were used the present study, a total of $12(92.31 \%)$ polymorphic loci detected in the present study indicate the effectiveness of RAPD techniques to study polymorphism and genetic relatedness in the five different Red Chittagong population.

Gene frequency: The highest and the lowest level of gene frequency value $(0.9590$ and 0.0440$)$ was observed in allele 0 and 1 with BMC1222-2 locus and only one monomorphic locus (OPB07-1) was found (Table 2). The RAPD method only score the homozygous and heterozygous dominant allele but unable to detect homozygous recessive one ${ }^{[19]}$.

Genetic variation: Seven to ten polymorphic (53.85$76.92 \%$ ) loci present in all the five populations (Table 3) indicated that sufficient level of genetic variation was observed among different individuals of each population. The Nei's gene diversity and Shannon's information indicated that the highest diversity found in Anwara (0.2925) (Table 3). The highest gene diversity indicated that the Anwara RCC population is alarming to deteriorate with native or exotic blood than other populations. On the other hand, the Chandonish showed lowest genetic diversity (0.2147).

Pair Wise genetic distance: The minimum distance was found between Satkania and Chandonish (0.0092) (Table 4). It's indicated that the genetic relationship between these populations was closer than others. On the other hand, maximum distance was found between RCC BLRI and Potia. Over all, the pair wise genetic distance values were low for all populations and it indicated that the RCC population was closer related.

Dendrogram: Dendrogram based ${ }^{[20]}$ genetic distance using UPGMA depicted the relationship among five population of RCC (Fig. 2). The dendrogram segregated the five population of RCC into two clusters: RCC BLRI and Anwara is one cluster whereas Satkania, Chandonish and Potia made another cluster. These cluster indicated that RCC BLRI was belongs to Anwara population.

\section{CONCLUSION}

It can be concluded that overall genetic variation in each population from ${ }^{[20]}$ gene diversity, Shannon's Information index and proportion of polymorphic loci points of views is relatively higher for a prescribed breed.

The differences of between population genetic variations in the five studied populations were low and therefore, there is scope of selective breeding (like, ONBS) for future improvement of Red Chittagong Cattle.

\section{REFERENCES}

1. Mondal, S.C., M.M. Alam, M.M. Rashid, M.Y. Ali and M.M. Hossain, 2005. Comparative study on the productive and reproductive performance of different dairy genotypes reared in Bangladesh Agricultural University Dairy Farm. Pak. J. Nutr., 4: 222-225.

http://www.pjbs.org/pjnonline/fin227.pdf 
2. Khan, M.K.I., K.S. Huque, A.G. Miah and M.J. Khatun, 2000. Study on the performance of Red Chittagong cow under different production system. Pak. J. Biol. Sci., 2: 318-319. http://www.ansijournals.com/pjbs/2000/318-319.pdf

3. Vasconcellos, L.P.M.K., D.T. Talhari, A.P. Pereira, L.L. Coutinho and L.C.A. Regitano, 2003. Genetic characterization of Aberdeen Angus cattle using molecular markers. Genet. Mol. Biol., 26: 133-137. DOI: $10.1590 /$ S1415-4757200300020005

4. Mukesh, M., M. Sodhi, S. Bhatia and B.P. Mishra, 2004. Genetic diversity of Indian native cattle breeds as analysed with 20 microsatellite loci. J. Anim. Breed. Genet., 121: 416-424. DOI: 10.1111/j.1439-0388.2004.00468

5. Negi, M.S., M. Devic, M. Delseny and M. Lakshmikumaran, 2000. Identification of AFLP fragments linked to seed coat colour in Brassica juncea and conversion to a SCAR marker for rapid selection. Theor. Applied Genet., 101: 146-152. DOI: 10.1007/s001220051463

6. Miklas, P.N., J.R. Stavely and J.D. Kelly, 1993. Identification and potential use of a molecular marker for rust resistance in common bean. Theor. Applied Genet., 85: 745-749. DOI: 10.1007/BF00225014

7. Dakir, E.H., M.L. Ruiz, P. García and M.P. Vega, 2002. Genetic variability evaluation in a Moroccan collection of barley, Hordeum vulgare L., by means of storage proteins and RAPDs. Genet. Resour. Crop Evol., 49: 619-631. DOI: 10.1023/A: 1021228730714

8. Gwakisa, P.S., S.J. Kemp and A.J. Teale, 1994. Characterization of Zebu cattle breeds in Tanzania using random amplified polymorphic DNA markers. Anim. Genet., 25: 89-94. http://cat.inist.fr/?aModele $=$ afficheN\&cpsidt $=4066798$

9. Kantanen, J., J. Vilkki, K. Elo and A. Maki-Tanila, 1995. Random amplified polymorphic DNA in cattle and Sheep: Application for detecting genetic variation. Anim. Genet., 26: 315-320. http://cat.inist.fr/?aModele $=$ afficheN\&cpsidt $=3703020$

10. Welsh, J. and M. McClelland, 1990. Fingerprinting genomes using PCR with arbitrary primers. Nucleic Acids Res., 18: 7213-7218. http://www.ncbi.nlm.nih.gov/sites/entrez

11. Williams, J.G.K., A.R. Kubelik, K.J. Livak, J.A. Rafalski and S.V. Tingey, 1990. DNA polymorphisms amplified by arbitrary primers are useful as genetic markers. Nucleic Acids Res., 18: 6531-6535.

http://www.ncbi.nlm.nih.gov/sites/entrez
12. Roe, B.A., J.S. Crabtree and A.S. Khan, 1996. DNA Isolation and Sequencing: Essential Techniques Series. John Wiley and Sons, New York, USA.

13. Glasel, J.A., 1995. Validity of nucleic acid purities monitored by $260 \mathrm{~nm} / 280 \mathrm{~nm}$ absorbance ratios. Biotechniques, 18: 62-63. http://www.citeulike.org/user/kevinchannon/article 12340261

14. Nei, M., 1973. Analysis of gene diversity in subdivided populations. Proc. Natl. Acad. Sci. USA., 70: 3321-3323.

http://www.pnas.org/content/70/12/3321.full.pdf+h tml

15. Yeh, F.C., R.C. Yang, T.B.J. Boyle, Z.H. Ye and J.X. Mao, 1999. POPGENE, the user-friendly shareware for population genetic analysis. Molecular Biology and Bitechnology Centre, University of Alberta, Canada. http://www.ipgri.cgiar.org/Training/Unit101/MolMarkers/PDF/volume2/13_\%20Appendix-9.pdf

16. Carvalho, V.P., C.F. Ruas, J.M. Ferreira, R.M.P. Moreira and P.M. Ruas, 2004. Genetic diversity among maize (Zea mays L.) landraces assessed by RAPD markers. Genet. Mol. Biol., 27:28-36. DOI: 10.1590/S1415-47572004000200017

17. Georg, E. and C. Weimann, 2007. Use of molecular markers for evaluation of genetic diversity and in animal production. Arch. Latinoam. Product. Anim., 15: 63-66.

http://www.alpa.org.ve/PDF/Arch\%2015\%20Supl/ p_georgerhardt.pdf

18. Smith, O.S., J.S.C. Smith, S.L. Bowen, R.A. Tenborg and S.J. Wall, 1990. Similarity among a group of elite maize inbreds as measured by pedigree, F1 grain yield, heterosis and RFLPs. Theor. Applied Genet., 80: 833-840. DOI: 10.1007/BF00224201

19. Chawla, H.S., 2000. Introduction to Plant Biotechnology. Oxford and IBH Publishing Co. Pvt. Ltd., New Delhi, India. http://envis.kuenvbiotech.org/books.htm

20. Nei, M., 1972. Genetic distance between populations. Am. Nat., 106: 283-292. DOI: $10.1086 / 282771$ 